\title{
Social determinants in ocular diseases
}

This article was published in the following Dove Press journal:

Clinical Optometry

3 December 2010

Number of times this article has been viewed

\section{Reza Gharebaghi' \\ Fatemeh Heidary' \\ Roghayeh Heidary' \\ Mohammad Reza Vaez \\ Mahdavi² \\ 'Middle East Cancer Institute, Tehran, Iran; ${ }^{2}$ Social Justice and Health Department, Shahed University Medical Sciences Research Center, Tehran, Iran}

\begin{abstract}
Data on the prevalence of blindness indicate that developing countries have a higher incidence of blindness. Additionally, some studies indicate that inequality of access to suitable eye care services may contribute to visual impairments. Social determinants of health are general circumstances shaped by a wider set of forces: economic, social, and political. We suggested, for the first time, close collaboration between international agencies at the global level in order to evaluate and monitor the role of social determinants in ocular diseases and to implement new strategies to overcome social factors that limit access to eye care services. This idea has been named 'social determinants in ocular diseases'. These collaborations may present new insights into the effect of social determinants on visually impaired individuals during the period until the achievement of VISION 2020.
\end{abstract}

Keywords: blindness, social determinants, ocular disease, eye care, VISION 2020

\section{The right to sight}

VISION 2020 was launched by the World Health Organization (WHO) and the International Agency for the Prevention of Blindness (IAPB). It seeks to eliminate the major causes of avoidable blindness in order to guarantee the right to sight to people all over the world, particularly the millions of needlessly blind. It aims to eliminate the main causes of avoidable blindness by 2020 by bringing together governments, eye care professionals, nongovernmental agencies, and other organizations in order to facilitate the planning, development, and implementation of sustainable eye care programs. $^{1}$

\section{Vision and social development}

Many causes of avoidable blindness in low-income countries are directly related to poverty. They include hunger, malnutrition, and limited access to health, education, water, and sanitation services. ${ }^{2}$ Global data on the prevalence of blindness indicate that developing countries have a higher incidence of blindness as compared with developed countries. ${ }^{3}$ It has been shown that seven of the eight United Nations Millennium Development Goals (MDG) may be linked to the implementation of VISION 2020. ${ }^{4}$ Several available studies have clearly shown the relationship between poverty, socioeconomic status, and health. ${ }^{4-6}$ Increased socioeconomic status has been known to have considerably reduced blindness from malnutrition and diseases like trachoma and conditions resulting from vitamin A deficiency. ${ }^{4}$ Furthermore, some studies indicate that inequality of access to suitable eye care facilities may also contribute to visual impairments. ${ }^{7}$
Correspondence: Roghayeh Heidary Middle East Cancer Institute, PO Box 14155-1856, Tehran, Iran Tel +982 I 4449 I457

Fax +98 $214449 \quad 1457$

Email roghayehheidary@gmail.com 


\section{Social determinants of health: the solid facts}

Health inequities are avoidable inequalities in health among different social groups. These inequities may also arise from inequalities among countries. Socioeconomic conditions and their effects on people's lives determine their risk of and capacity to prevent and treat illness. ${ }^{8}$

There is a need for a major effort that complements both the development of health systems and poverty relief in order to reduce inequalities in health across the world. Social determinants of health (SDH) are circumstances shaped by a wider set of forces: economic, social, and political. In 2005, the WHO launched the Commission on Social Determinants of Health (CSDH) to review the evidence of health inequities, provoke societal debate, and recommend policies with the goal of improving the health of the world's most vulnerable people. Data on the SDH were published in Social Determinants of Health: The Solid Facts, a comprehensive report by the WHO., 10

\section{Potential dual role of IAPB and CSDH}

Eye care for people with lower socioeconomic status through population-based prevention strategies is one of the main concerns. The needs of those at a high risk of visual impairments should be addressed. It is vital to have a policy continuum that takes into account all the conditions that affect the ocular risk factors and their determinants, including social support, education, social security, equity in health care services, and elimination of stressful conditions. The most appropriate health care service entry point identified for addressing equity issues seems to be primary care. Other constituents of a public health strategy that addresses inequities in ocular diseases include a systematic approach to prevent risk factors and their social determinants, measures to ensure equity in the utilization of limited public sector resources, and recognition of the participatory role of civil society. Furthermore, government commitment to place equity and health at the center of all governmental policies may be considered a vital factor.

The above facts collectively suggest the close collaboration between international agencies especially CSDH and IAPB at the global level in order to evaluate and monitor the role of social determinants in ocular diseases and to implement new strategies to overcome social factors that limit access to eye care services. These strategies may report globally, for the first time, as the 'social determinants in ocular diseases'. These collaborations may also offer new insights into the effect of social determinants on visually impaired individuals during the period until the achievement of VISION 2020 and, therefore, warrants further research.

\section{Disclosure}

The authors report no conflicts of interest in this work.

\section{References}

1. Lewallen S, Kello AB. The need for management capacity to achieve VISION 2020 in Sub-Saharan Africa. PLoS Med. 2009;6(12): e1000184.

2. Blindness, Poverty and Development. The impact of VISION 2020 on the U.N. millennium development goals. Available from: www. vision2020.org/documents/iapb-mdgs.pdf. Accessed 2010 May 5.

3. Thylefors B, Négrel AD, Pararajasegaram R, Dadzie KY. Global data on blindness. Bull World Health Organ. 1995;73(1):115-121.

4. Khanna R, Raman U, Rao GN. Blindness and poverty in India: the way forward. Clin Exp Optom. 2007;90(6):406-414.

5. Salive ME, Guralnik J, Christen W, Glynn RJ, Colsher P, Ostfeld AM. Functional blindness and visual impairment in older adults from three communities. Ophthalmology. 1992;99(12):1840-1847.

6. Dandona R, Dandona L. Socioeconomic status and blindness. $\mathrm{Br} J$ Ophthalmol. 2001;85(12):1484-1488.

7. Gilbert CE, Shah SP, Jadoon MZ, et al. Poverty and blindness in Pakistan: results from the Pakistan national blindness and visual impairment survey. BMJ. 2008;336(7634):29-32.

8. What are health inequities or inequalities? Available from: http://www. who.int/social_determinants/thecommission/finalreport/key_concepts/en/. Accessed 2010 Jun 16.

9. Marmot M. Social determinants of health inequalities. Lancet. 2005; 365(9464):1099-1104.

10. World Health Organization. Social Determinants of Health: The Solid Facts. Available from: http://www.euro.who.int/_data/assets/pdf_ file/0005/98438/e81384.pdf. Accessed 2010 Aug 20.
Clinical Optometry

\section{Publish your work in this journal}

Clinical Optometry is an international, peer-reviewed, open access journal publishing original research, basic science, clinical and epidemiological studies, reviews and evaluations on clinical optometry. All aspects of patient care are addressed within the journal as well as the practice of optometry including economic and business analyses. Basic and clinical

Submit your manuscript here: http://www.dovepress.com/clinical-optometry-journal

\section{Dovepress}

research papers are published that cover all aspects of optics, refraction and its application to the theory and practice of optometry. The manuscript management system is completely online and includes a very quick and fair peer-review system, which is all easy to use. Visit http://www.dovepress. com/testimonials.php to read real quotes from published authors. 